\title{
Formation of Youth Identity in Indonesian Islamic Chick Lit
}

\author{
Novita Dewi \\ The Graduate Program of the English Language Studies, Sanata Dharma \\ University, Tromol Pos 29, Mrican, Yogyakarta 55002, Indonesia \\ e-mail:novitadewi9@gmail.com
}

\begin{abstract}
This paper is to argue that literature studies may help reveal the formation of young Indonesian female Muslim identity by looking at the books they read and write. It will particularly discuss two popular Islamic Chick Lit Santri Semelekete [Funky Islamic Boarding School Girl] (2005) by Ma'rifatun Baroroh and Jilbab Britney Spears: Catatan Harian Sabrina [Britney Spears' Headscarf: Sabrina's Diary] (2004) by Herlinatiens. The first part of the discussion will examine some external aspects such as physical presentation, biographical details of the authors, and publication-related matters. Then, using such side-line information, the next part will discuss the novels' contents to see in what way they offer some cultural analysis of youth identity in contemporary Indonesian society.
\end{abstract}

Key words: Chick Lit, identity, consumer culture

I, Hasan the son of Muhammad the weigh-master, I, Jean-Leon de Medici, circumcised at the hand of a barber and baptized at the hand of a pope, I am now called the African, but I am not from Africa, nor from Europe, nor from Arabia. I am also called the Granadan, the Fassi, the Zayyati, but I come from no country, from no city, no tribe. I am the son of the road, my country is the caravan, my life the most unexpected of voyages... From my mouth you will hear Arabic, Turkish, Castilian, Berber, Hebrew, Latin and vulgar Italian, because all tongues and all prayers belong to me. But I belong to none of them. I belong only to God and to the earth, and it is to them that I will one day soon return.

Amin Maalouf, Leo the African (1988)

This paper begins with the self-introduction of Hasan al-Wazzan a.k.a. Leo Africanus through the elegant account of Amin Maalouf to show how unstable and copious identity is. When compared to that of Leo the 
African, our today's world is more interdependent so as to make identity become even more porous and inevitably mixed. This paper is to examine the formation of identity by young female Indonesian Muslims through the books they read and write. Believing that literature is a distillation of human experiences, the discussion attempts to show the significance of probing into the production and consumption of literature by placing it amidst the consumer culture phenomena that permeate almost every aspect of the society nowadays. Young Muslim Indonesian readers, for example, have shared worldwide consumption of light, modern fiction written by and for females through their choice of Islamic Chick Lit. Here, "Islamic Chick Lit" is a conveniet term to refer to the crossover between the socalled "Sastra Pesantren" (Munawwar, 2008), that is, literary works written by the Islamic boarding school community, and the regional variety of Western genre fiction whose target readers are modern and stylish women in their 20s and 30s. Indeed, it is a social phenomenon that Islamic Chick Lit has become one sub-genre fiction that appeals to Indonesian teenaged Muslim readers, especially the female ones. Seen from the kind of books they consume, these young women have made urbanity as their disposition. The fact that they have favored urbanity as a trend may help us see the other face of the Indonesian Muslim society which may have been distorted by the prevailing discourse which views the Muslims as post-9/11 terrorist groups, and Islam, an omnipresent threat.

Here, the importance of studying popular literature is unquestionable. So far, the bulk of scholarship on the representation of women in Indonesian literature published in post-Suharto era have mostly paid attention to serious writing (Hartley, 1999; Aveling, 2002), rather than to popular fiction. Although there has been a growing body of literature on women's popular fiction, these studies have focused on its history, production and consumption (Djundjung, 2004; Rahmanto, 2006); and little is said about the proliferation of a particular sub-genre like Islamic Chick Lit.

This paper, therefore, will argue that in a country where Islam, the religion of the majority, is lately seen as being fraught with women's rights, the growth of Islamic Chick Lit may invite such questions as what the works say, what they mean to the authors and the readers as well as what they contribute to the larger society in which these young women live. The discussion that follows will limit itself to examining two runaway success novels in the 2000s: Santri Semelekete [Funky Islamic Boarding School 
Girl] (2005) by Ma'rifatun Baroroh and Jilbab Britney Spears: Catatan Harian Sabrina [Britney Spears' Headscarf: Sabrina's Diary] (2004) by Herlinatiens. The first part of the discussion will frame both novels externally by examining several aspects like their physical presentation, biographical details of the authors, and pertinent issues surrounding their publication. Then, using the background information, the subsequent section will examine the novels' contents to see in what way they may inform us about youth identity in contemporary Indonesian society.

\section{“IT’S HIP. IT’S SMART. IT’S ALL ABOUT YOU”}

The slogan borrowed for the sub-head of this section is the most-often quoted definition of Chick Lit given by Chicklit.com. Without a doubt, the slogan's interpellating effect on teenaged readers in making them identify themselves with the major characters in Chick Lit, as observed by Djundjung (2004), is also evident in the novels to be discussed soon, when we glimpse through the reasons and passion behind their publication. To begin with their outer look, Santri Semelekete (henceforth SS) and Jilbab Britney Spears (henceforth JBS) are variants to the covers of what Glasburgh (2006) described as "books with the pastel-colored covers depicting swirly, cartoon-ish women [that] are selling wildly", since the young women so depicted are all wearing headscarves or jilbab with bright and bubbly colours. Printed on the front and back covers of JBS is a logo signed Remaja Islami: TeenLit [Islamic Youth: Teen Lit] with a drawing of a young woman's pretty face adorned with a dark pink jilbab, while SS has no such emblem. Note should be taken here that "teen lit" is yet another sub genre especially marketed to teenagers. To return to the JBS cover, from head to toe, to match their headscarves, these chic girls appear very fashionable. All wear trendy, polite, and not revealing outfits varying from T-Shirt, jeans, miniskirts to school uniform, coupled with stylish shoes or sandals -quite in line with the "trade mark" or image often created for characters in this particular genre (Rahmanto, 2006, p. 3). Here, the hip and smart presentation of the books was cleverly tailor-made to invite specific target readers who would quick to consume such an offer. The back covers of both novels, too, carry some promotional words alluring readers to the thrills in store.

To the old maxim "Don't judge the book by its cover", SS may positively say "Yes", because the joyful, somewhat mischievous but smart- 
looking girl in her personalized school uniform of the cover, looks like the author whose smiling photo and biodata are found on the last page of the book. Born in Magelang, Central Java, April 25, 1986, Ma'rifatun Baroroh spent her entire education in the Pondok Pesantren or Islamic Boarding School where she practiced her writing talent to publish in the schools' wall magazine. She is to date a prolific writer publishing her works for quite prestigious publication, participates in various literary activities, while becoming a member of the Yogyakarta-based writers' forum. As it will be clearer later, the main character in SS is presumably modeled on its author.

Four years older and her birthday falls one day later than Baroroh, the writer of JBS, Herlinatiens, the pen name of Herlina Tien Suhesti, was born in Ngawi, East Java, April 26, 1982. Now a graduate student at the Religious and Cultural Studies, Sanata Dharma University, she, like Baroroh, has started publishing poems, short stories, essays and novels as well as winning many writing awards since she was a student. Her bestselling novel is the controversial Garis Tepi Seorang Lesbian [The Margin of a Lesbian] (2003), derided by certain groups of people but praised by the feminist scholar Saskia E. Wieringa in her Foreword to the book as "a powerful political tool" for lesbians not to feel guilty or ashamed of the chosen lifestyle while advocating society's acceptance of it.

Published for the first time in August 2005, SS was reprinted twice the next year, while JBS was published in September 2004, and reached the second printing within a month. The books were respectively published by the branch divisions of two flourishing publishers, LKiS Press and Galang Press, both based in Yogyakarta - home for many publishing houses. A few words about the publishers are necessary here.

The publisher of SS is Matapena, one division in LKiS (Lembaga Kajian Islam dan Sosial) or Institution of Islamic and Social Studies, founded in Yogyakarta in the 1990s during the repressive New Order government of Suharto. The genesis of LKiS was the university students' movement holding group discussions, seminars and workshops as well as demonstrations to extend their concerns over sociopolitical issues of the day. Pioneered by the ardent students of IAIN Sunan Kalijaga (now Islamic State University), the group edited, translated and published books formerly for internal circulation before it became available for public purchase. What has made LKiS acceptable for wider community is the institution's spirit for pluralism and commitment to understanding the 
discourse of Islam, which is transformative and tolerant, to agree with the Indonesian pluralistic society.

As for Galang Press, whose sub-division Pustaka Anggrek published JBS, the name "Galang" meaning "to guard" was so chosen to suit the mission of the enterprise to "guard freedom, sharpen ideas, and respect pluralism”, by publishing concoction of different flavours of books from different authors with different backgrounds and lifestyles As it is, selfconfessional is the type of books favored by this publishing house, which has often been dubbed as having sold sensational and sensual kind of books with sexuality themes ('Profil' Galang Press Web Blog, 1999). To add some notes, many newspapers' articles claim that Galang Press has penchant for publishing fiction of which the titles often allude to physical pleasure such as Jangan Main-main dengan Kelaminmu [Don't Toy with Your Genital], Jangan Lepas Jilbabku [Don’t Strip My Jilbab Off], Jangan Kau Lihat Kelaminku [Don't Look at My Genitals].

The backgrounds of the respective chick lit writers and the publishers of their books above may shed light on the kind of book the young Muslim readers in Indonesia are likely to consume with which they help shape their identity. The next part of this paper will therefore examine SS and JBS by focusing on how the books can be situated within the larger sociocultural context and political economy of their emergence. Books like SS and JBS are well read and relatively affordable (sold at Rp. 15,000 - 30,000 or one dollar fifty cents to three US dollars per copy); thus, it is hard to ignore their potential influence it could have on the readers.

\section{YOUTHS’ DREAM OF MODERN MORAL MUSLIMS}

Like any genre fiction, $S S$ and JBS have specific topics, settings and characters to suit the imagined identity of the prospective readers; and the identity in question is metropolitan Muslim. The "package deal" that comes with this identity is becoming modern and moral not only in appearance but inwardly as well. Falling into the category of girl high school/freshmen genre, SS and JBS revolve around problems ranging from love and parental relationships, the character's entrance to womanhood, the search for socio-cultural and religious self-identity, to the finally found personal piety. Sometimes they suggest an attempt to disrupt and break into the dominant authority (teachers, parents, religious leaders), but eventually the power they seek to challenge is the desire to embrace modernity and 
inborn longing for piety to fit in comfortably in the public sphere. Should there be any message, it would be the manner with which today's young Muslim women resist the stereotypical image of the past ("subservient," "orthodox") for the present interpretation (“assertive," “modern”).

The discussion will focus on how these young women aspire to be modern and pious. Attention will be paid to the ways in which two Islamic attributes, Santri and Jilbab as used in the title, are played down here. SS and JBS seem to invite readers to see critically whether peole use or abuse these two Islamic paraphernalia when they proclaim themselves as Muslims.

To begin with the title, the paradox shown in each title is in fact signposts to the books' contents that lampoon serious approach to understanding Islam and other social and cultural issues involving the youths. The books imply that we can glean knowledge from the ways young people embrace religiosity through their everyday experiences. In SS, the word "Santri" which means devout Islam vis-à-vis nominal Islam is collocated with the word "Semelekete" meaning frivolous and funky. Similarly, contradiction in terms is also evident in JBS. The word "Jilbab" is usually associated with commendation for women to cover their body. On the contrary, we find it hard to recall which part of Britney Spears' body is seen covered. The titles of the novels thus signify that "Santri", "Semelekete", "Jilbab" and "Britney Spears" are all signifiers to be understood at different textual levels.

Endang Jumilah who prefers to be called Enjoy in SS is a quite smart high school student forcedly transferred to a rundown, seedy, cramped pesantren (Islamic boarding school), much to her disappointment as an only daughter of successful business parents accustomed to good life and lack of discipline. Coming to the boarding school is like a "reality check" for Enjoy, because she finds more mischief here; but it is from the very place that the girl in the end becomes morally more mature. She struggles between her curiosity to taste a thing or two about glamorous city life of young people today and the necessity to stay away from premarital sex, which often becomes part and parcel of that lifestyle. Frivolous as she does, Enjoy manages to keep her virginity intact. She witnessed her two friends being unluckily penalized and expulsed from the boarding school for less serious misconduct than hers. The remorseful Endang Jumilah now thanks God for not punishing her despite the past wrongdoings. 
To abide to the college regulation, Ruth Sabrina Rabello of the second novel JBS wears Jilbab only when going to her campus where she remains a stranger, probably partly due to her Caucasian look. Her single parent mother who disapproves of her wearing jilbab is no friend of her either, for the older woman keeps bringing home male friends. She is insensitive to her daughter who is herself longing for a father and a boyfriend alike. Ignored by her mother and betrayed by her best friend about a male friend she likes, the loner and trying-to-be-good Muslim Sabrina, who hardly performs five daily prayers, finally recognizes God's loving kindness. She thanks God the Merciful for the long awaited return of her father to the family and, more importantly, two boyfriends for her to choose.

Here, seen from the formulaic plotlines, fairytale-ish happy endings and ideal character portrayals, SS and JBS are seemingly no difference from other Chick Lit which mostly depicts the life journey and/or love affairs of young modern women (Djundjung, 2004; Rahmanto, 2006). Thus, the Islamic elements in $S S$ amd JBS are put more for a décor to add to the identity crisis story. Howver, the fact that $S S$ titillates the image of the Islamic boarding school and the character's perkiness, while JBS tricks the readers with Jilbab and "Britney Spears", the standard formula seems to be interrogated. The narratives of the young women in SS and JBS may provide an outlet for their generation to tell their own (life) stories. Both novels allow their young readers to construct their identities, while challenging the likely negative representations of today's young generation: They are not immune to the allurement of sex, party and drugs as signs of modernity, but their inherent desire for spirituality is equally present.

Dream of modernity is as strong as the moral one, and this has to be reconciled first with the Islamic identity attached to them. Invariably in SS and JBS, the young women listen to Mariah Carey, Eric Clapton, but there is no mention of, predictably, anyone listening to Dangdut music, let alone Islamic songs; and the only Indonesian artist referred to is Bertrand Antolin who barely has Asian look. In Enjoy's lodging, image of Avril Lavigne appears everywhere from T-Shirt to pint-up poster which can be removed from the wall with other posters should there be unexpected room inspection.

To add more signs of modernity, as a 'convent' girl, Enjoy is not supposed to sneak out with her friends from the boarding school to eat in “KFC, McD, Papa Ron's, Pizza Hut” (SS, 35), or to do window-shopping 
from mall to mall, much less going to cafés sipping drink and smoking. Unlike Enjoy, Sabrina whose breakfast is Western enough -bread, butter and cheese-eating funky, junky food is not her interest, and she can get her mum's chauffeur drive her to anywhere and wait for her.

Next, modernity and morality continues to baffle the characters, and this dilemma is attached to the narratives by means of criticism to such establishments as school and family. When arriving home drunk and drained, Sabrina's mother is a bad example for her adolescent daughter. Sabrina was flabbergasted by condoms, contraceptive devices and pregnancy test her mother neglectfully left in the bathroom. Similarly, Enjoy's parents, as commonly happened in modern family, are overly busy, hence unable to either watch over or give guidance to their daughter who grows wild and rebellious day by day. The school Enjoy goes to is slack and poor in academic atmosphere. The teachers in her school close their eyes to the students' needs, and the students have no respect either to the teachers. In the boarding school, again, Enjoy encounters a shocking truth: lesbianism and casual sex are not uncommon. Here, the older generation is as culpable as the young one for failures in reconciling modernity and morality; and, the books suggest, the young women portrayed seem to fare better in adjusting to modernity than their seniors do, as it will be illustrated below.

We need to observe further how the young women in the novels conceive the jilbab-wearing as part of the new Muslim fashion in vogue with modernity. In fact, to understand how young people treat these two belongings associated to Islamic identity is to recognize their role in producing meanings. Here, SS and JBS may provide explanation for the young women's excitement in wearing jilbab. The explanation might be slightly different from scholarly accounts, but perhaps not necessarily less plausible. Admittedly, jilbab-wearing is now an outdated issue, only enlivened again a few years ago in relation to dress-code in the heat of the debate on Pornography/Pornographic-Action Draft Bill. Earlier on, Suharto's eldest daughter Tutut became the trendsetter in jilbab-wearing in the 1990s when Suharto's Islamic policy necessitated his family to put on pious Muslim image. It is easy to predict the political economic implication of this trend with which fashion designers made fortunes when artists, politicians and other public figures are also in the game. In SS and JBS, however, the issue is taken on lightheartedly. 
Enjoy tells the readers that there are two kinds of jilbab: "kerudung gaul" meaning wearing jilbab to be "cool", and "kerudung sampir", that is, wearing it to suit formal occasions like wedding, Idul Fitri and other Islamic holidays (SS, 24). She then continues playfully to explain why and how to wear the stylish jilbab, that is, by tightening the front and neck parts of the cloth so that the wearer can flaunt her beautiful chest. This witty explanation can better tell us why suddenly the "kerudung gaul" [stylish headscarf] is all the rage. This fashion craze is also illustrated clearly in JBS through Sabrina's comments in her diary. This tallish young woman who always envies her full-breasted mother wants to appear modish in her Islamic outfit, in contrast to those college friends who wear jilbab to match their super tight tops or those with very low neckline and see-through blouses. While JBS signifies the absence of a story of jilbab for itself, printed on the back cover of the book is Sabrina's reflection. She says that striving for purity is overwhelmingly difficult, not as easy as putting on jilbab. This is to say that this new Muslim fashion hardly has anything to do with personal statement or identity assertion, i.e. either to become a moderate or radical follower of Islam. These young women just want to be properly stylish. They dream to be modern and be moral at that. As it is, the option is to be sensually moral. Here, the characters' uncomplicated perspective on the difficult issue helps declare the otherwise hidden voice of the many unpretentious jilbab-wearing Indonesian women, for example.

Seen in this light, both works seem to comment on gradual transformation experienced by the Indonesian Muslim society in terms of fitting in the secular nature of the multi-racial and multi-religious nation. Hence, thanks to the generation who dare to cross border in order to move more easily in today's globalized world as exemplified by the metropolitan Muslim youngsters in Santri Semelekete and Jilbab Britney Spears, to say the least. Through the characters' everyday experiences, the books offer fascinating glimpses into the way young Muslims nowadays may cope with modernity on the one hand, and with the urgency to be moral on the other. To be spiritually stylish is the goal of these young women.

\section{CONCLUSION}

This paper has shown three interconnected issues of identity, literature and consumers. First, identities are manifold; and they all have the capacity both to construct and to destroy. As such, identities are not fixed. In Santri 
Semelekete [Funky Islamic Boarding School Girl] and Jilbab Britney Spears: Catatan Harian Sabrina [Britney Spears' Headscarf: Sabrina's Diary], identities can be formed, reformed and even deformed by varied institutions like family, pesantren and popular culture. It appears that identities that popular culture has helped to create are the most palpable one, as they become lifestyles (arts de vivre), very well accepted and appreciated by the devoted adopters (Bourdieu, 1984, p. 48). Albeit dominated and often seen tasteless by the mainstream aesthetic, the ways of life borne mostly out of popular culture, help explain why plethora of identities emerge and fought for by different classes in society.

The second issue is economy of consumption. Books like SS and JBS are indicative of big business; some were printed as many as 3,000 copies in each publication (This information is supplied by Tri Muryono from the Marketing Division of LKiS Press as of early 2009). Such 'hip' titles like Santri Nekad [Unscrupulous Santri], Love in Pesantren and Santri Tomboy flood the market, targeting young readers who are fond of using the trendy language of their own so named bahasa gaul_[cool colloquial language], i.e. blend of Indonesian, English, Jakartan and other dialects. We can imagine here how powerful is the production and consumption of Chick Lit like this in supporting identity formation. In light of this, identities are unsteady signifiers fought for by different competitors.

Thirdly, corollary to the fact that lifestyle has become an object of struggle and site of competition as shown by the above discussion, it is important to extend literature studies to discussing literature as practiced in cultural studies, rather than understood in the Arnoldian concept of "literature being the best that has ever been thought and said in the world". Here, studies, imagination and resistance are imminent sites jostling for attention. The price is high if we do not gear up studies in literature toward this interdiscplinary direction. As argued elsewhere, literature study would likely lose its appeal, should it fail to engagge and converse with other fields in the humanities within the now interreliant , transnational context (Dewi, 2009a; Dewi, 2009b).

As a final remark, this paper has shown that Islam can be attuned with Chick Lit. By juxtaposing two Islamic Chick Lit novels against social realities and cultural codes practiced by various segments of society, in this case, the young female Muslim consumers, what emerges is deconstruction of the fear/fun binary. The dominating notions are proved incorrect: first, Islam in Indonesia is always associated with fundamentalism perilous to 
the nation-state, and second, that nothing of serious concerns can be gleaned through popular literature. The young Muslim women illustrated in the novels may not be aware anymore of their Islamic identity or whatever identity they have been so far searching for, when, at the end of the day, they pray in thankfulness to God, longing to embrace God, recognizing, like Leo the African quoted in the opening of this paper, that they belong and one day will return to God.

\section{REFERENCES}

Aveling, H. (2002). Supernova and contemporary writing by women in Indonesia. Paper presented at the $14^{\text {th }}$ Biennial ASAA Conference, Hobart, Tasmania.

Baroroh, M. (2005). Santri semelekete. [Funky islamic boarding school girl]. Yogyakarta: Matapena.

Bourdieu, P. (1984). Distinction: A social critique of the judgment of taste. (R. Nice, Trans.). Cambridge: Harvard University Press.

Dewi, N. (2009a). Quo vadis English studies di Indonesia? [Quo vadis English studies in Indonesia]. In S. Wibowo (Ed.), Manusia teka-teki yang mencari solusi [Puzzled people in search of solution] (pp. 199-211). Yogyakarta: Kanisius.

Dewi, N. (2009b). Literature: The "know-what", the "know-how" and the "knowwhy". Paper presented at the 13th International Conference on English in Southeast Asia, Singapore.

Djundjung, J. M. (2004). The construction of urban single career woman in Indonesian chick lit Jodoh Monica [Monica’s soul mate]. k@ta 6(2), 122 144.

Glasburgh, M. (2006). Chick lit: The new face of post feminist fiction? Unpublished master thesis, University of North Carolina, Chapel Hill.

Hatley, B. (1999). New directions in Indonesian women's writing. Asian Studies Review, 23(4), 49-50.

Hatley, B. (2002). Postcoloniality and the feminine in reading Indonesian literature. In K. Foulcher, \& T. Day (Eds.), Clearing space: Postcolonial readings of modern Indonesian literature (pp. 145-182). Leiden: KITLV.

Hendrarti, I. (1994). Producing and consuming women's popular fiction: Reflections on writing and reading in Indonesia. Paper presented at the Monash Workshop on South-east Asian Women, Melbourne.

Herlinatiens. (2003). Garis Tepi Seorang Lesbian. [The Margin of a Lesbian]. Yogyakarta: Galang Press.

Herlinatiens. (2004). Jilbab Britney Spears: Catatan harian Sabrina. [Britney Spears' headscarf: Sabrina’s diary] Yogyakarta: Pustaka Anggrek.

Maalouf, A. (1988). Leo the African. London: Abacus. 
Munawar, R. (2008). Ledakan sastra pesantren mutakhir: Cinta, kritisisme, dan industri. [Islamic boarding school fiction: Love, criticism, and industry].

Retrieved March 10, 2011, from http://.pdfwindows.com/.../ledakan-sastrapesantren-mutakhir--cinta--kritisisme--industri/

Rahmanto, B. (2006). Teenlit dan chicklit sebagai jenis baru dalam cipta novel, serta bagaimana komunitas sastra menyikapinya [Teenlit and chick lit as new genres in literature and how the literary community deals with this]. Arah Reformasi Indonesia, 32, 1-8.

'Profil' Galang press web blog (1999). Retrieved March 10, 2011, from http://www.galangpress.com/index_profil.php 